\title{
Rare hereditary hemochromatosis
}

INSERM

\section{Source}

INSERM. (1999). Orphanet: an online rare disease and orphan drug data base. Rare hereditary hemochromatosis. ORPHA:220489

Rare hereditary hemochromatosis comprises the rare forms of hereditary hemochromatosis $(\mathrm{HH})$, a group of diseases characterized by excessive tissue iron deposition. These rare forms are hemochromatosis type 2 (juvenile), type 3 (TFR2related), and type 4 (ferroportin disease) (see these terms). Hemochromatosis type 1 (also called classic hemochromatosis; see this term) is not a rare disease. 